\title{
Telaah potensi hybrid vigor sifat bobot badan pada silangan kambing Boer dan Jawarandu
}

\section{The study of hybrid vigor potency of body weight in Boer and Jawarandu goat crosbreed}

\author{
Sigit Prastowo, Yayang Resty Nurhayat, Ignatia Fanny Indah Widowati, \\ Tristianto Nugroho, Nuzul Widyas* \\ Program Studi Peternakan, Fakultas Pertanian, Universitas Sebelas Maret \\ Jl. Ir. Sutami 36A, Surakarta, Jawa Tengah
}

Submitted: 31 Oktober 2018, Accepted: 05 April 2019

\begin{abstract}
ABSTRAK: Upaya peningkatan produktivitas kambing lokal Indonesia dapat dilakukan dengan crossbreeding (persilangan) yang memanfaatkan efek heterosis atau hybrid vigor $(\mathrm{HV})$. Saat ini, kambing Boer telah banyak disilangkan dengan kambing Jawarandu untuk membentuk silangan kambing pedaging bernama Boerja.Penelitian ini bertujuan mengetahui nilai $\mathrm{HV}$ hasil persilangan kambing Boer dan Jawarandurelatifterhadap rerata kedua tetua (parents average)dan terhadap tetua betinanya. Sebanyak 504 data bobot badan $(\mathrm{BB})$ yang berasal dari pejantan Boer $(\mathrm{n}=6)$, betina Jawarandu $(\mathrm{n}=15)$, Boerja (Boer $\times$ Jawarandu) F1 $(\mathrm{n}=298)$, Boerja F2 $(\mathrm{n}=167)$ dan Boerja F3(n= 18) digunakan untuk analisis dalam penelitian ini. Metode persilangan dilakukan secara backcross, yaitu Boerja F2 didapatkan dari Boer $\left({ }^{\Uparrow}\right) \times$ Boerja F1 (ㅇ), sedangkan Boerja F3 dihasilkan dari Boer (さ) $\times$ Boerja F2 (ㅇ).Rerata dan simpangan baku BB kambing Boer, Jawarandu, Boerja F1, Boerja F2,

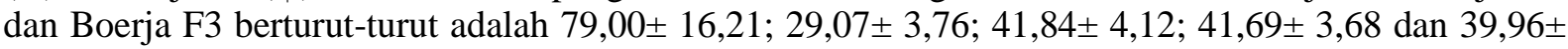
$4,97 \mathrm{~kg}$. Nilai HV kambing Boerja F1, F2, dan F3relatif terhadap kedua tetuanya berturut-turut sebesar -23 ; -31 ; dan $-34 \%$, sedangkan relatif terhadap tetua betina sebesar44,0, dan $-4 \%$. Berdasarkan nilai HV,dapat disimpulkan bahwa tampilan BBhasil silangankambing Boer dan Jawarandu paling optimalpada Boerja F1. Peningkatan proporsi bangsa kambing Boer pada hasil crossbreeding sampai F3, dalam penelitian ini, tidak meningkatkan tampilan produktivitas bahkan cenderung menurun.
\end{abstract}

Kata kunci : crossbreeding; hybrid vigor; kambing Boerja.

ABSTRACT: Crossbreeding program was an option in order to improve Indonesian local goat productivity. In general, crossbreeding is aimed to utilize the benefit ofheterosis (hybrid vigor: HV); where better offspring performance compared to its parents phenotype is expected. Currently, crossbreeding between Boer bucks and Jawarandu does is widely practised; resulting in a crossbred called Boerja. However, information regarding the HV effect were less available. Thus, this study aims to calculate HV in Boer $\times$ Jawarandu in relative to the mid-parental average, and relative to the dam phenotype. Mature body weight (BW) of 504 head of goat derived from Boer buck $(n=6)$, Jawarandu doe $(n=15)$, Boerja F1 $(n=298)$, Boerja F2 $(n=167)$, and Boerja F3 $(n=18)$ were analyzed. Backcross system was applied to produce Boerja F2 (Boer $\hat{\sigma}^{\lambda} \times$ Boerja F1 $q$ ) and Boerja F3 (Boer $\sigma^{\lambda}$ $\times$ Boerja F2 9 ). Result shows that BW in Boer, Jawarandu, Boerja F1, Boerja F2, and Boerja F3 were $79,00 \pm 16,21 ; 29,07 \pm 3,76 ; 41,84 \pm 4,12 ; 41,69 \pm 3,68$ and 39,96 \pm 4,97 $\mathrm{kg}$ respectively. The heterosis value of Boerja F1, Boerja F2, and Boerja F3 in relative to the parents average were $-23,-31$, and $-34 \%$, while in relative to the dam were 44,0 , and $-4 \%$ respectively. According to $\mathrm{HV}$ value, it is concluded that the most optimum result of Boer $\times$ Jawarandu crossbreeding was found in Boerja F1. Higher Boer breed proportion in F2 and F3 were found to have lower BW.

Keywords : crossbreeding; hybrid vigor; Boerja goat.

*Corresponding Author: nuzul.widyas@ staff.uns.ac.id

DOI: 10.21776/ub.jiip.2019.029.01.08 


\section{PENDAHULUAN}

Upaya peningkatan produktivitas ternak lokal dapat dilakukan melalui program persilangan (crossbreding) antara dua bangsa ternak yang memanfaatkan efek heterosis atau hybrid vigor (HV) (Oldenbroek and Waaij, 2015). Tujuan utama dari crossbreeding adalah menggabungkan sifat-sifat yang menguntungkan dari dua bangsa ternak agar keturunan yang dihasilkan memiliki tampilan produksi lebih baik dibanding dengan tetuanya (Crow, 2001). Meskipun mekanisme heterosis dalam meningkatkan produktivitas ternak belum dapat dijelaskan secara pasti, tetapi adanya pengaruh non-aditif, seperti: dominansi, over dominancedan epistasis yang mengubah expresi gen pengontrol sifatsifat pada ternak diduga sebagai penyebabnya (Crow, 2001; Williams et al., 2007).

Salah satu program crossbreeding yang popular di Indonesia adalah persilangan antara kambing Boer jantan (ternak eksotik) dengan kambing Jawarandu betina (ternak lokal) yang menghasilkan kambing Boerja (Nugroho et al., 2018). Kambing Boer adalah kambing yang berasal dari Afrika Selatan (Casey \& Van Niekerk, 1988), dan hidup pada lingkungan sub tropis kering (Solaiman, 2010). Kambing ini merupakan kambing tipe pedaging dengan pertumbuhan yang cepat, mampu tumbuh sampai 110 - $135 \mathrm{~kg}$ pada jantan, betina sekitar $90-100 \mathrm{~kg}$, dan memiliki pertambahan bobot badan harian 0,14 $0,18 \mathrm{~kg}$ per hari (Casey and Van Niekerk, 1988; Solaiman, 2010). Atas dasar keunggulan tersebut, kambing Boer sering dipilih untuk membentuk bangsa kambing baru tipe pedaging dengan cara menyilangkan dengan kambing lokal (Malan, 2000; Shrestha and Fahmy, 2007). Di sisi lain, kambing Jawarandu merupakan kambing lokal Indonesia, dikenal juga dengan nama kambing Bligon yang merupakan keturunan kambing
Peranakan Ettawa (PE) dan kambing Kacang (Budisatria, 2014). Kambing ini tercatat sebagai bangsa kambing yang memiliki sifat reproduksi yang prolifik (Wodzicka-Tomaszewskaet al., 1993).

Crossbreeding membentuk efek HV yang berdampak pada peningkatan produktivitas ternak (Kinghornet al., 1999; Oldenbroek and Waaij, 2015). Hasil persilangan akan menampilkan performan yang lebih unggul dibandingkan dengan rataan kedua tetuanya karena terjadipeningkatan heterozigositas dan penurunan homozigositas alel pada gen pengontrol sifat produksi. Hybrid vigor dari suatu karakter muncul sebagai akibat dari heterogenetik (Cassady, Young, and Leymaster, 2002) yaitu penggabungan antara berbagai gen yang mengontrol bermacam-macam sifat dalam membentuk sifat kualitatif maupun kuantitatif. Dijelaskan lebih lanjut bahwa sifat dominan, over dominance dan epistasis dari suatu gen merupakan sifat genetik non aditif yang lebih bertanggung jawab terhadap timbulnya HV positif atau negatif. Hybrid vigor positif diartikan sebagai ratarata penampilan suatu karakter keturunan hasil persilangan melebihi rata-rata penampilan kedua tetuanya, sedang $\mathrm{HV}$ negatif apabila rata-rata penampilan suatu karakter keturunan hasil persilangan lebih rendah dibanding rata-rata penampilan kedua tetuanya.

Beberapa kajian tentang ternak hasil crossbreeding sudah dilakukan terutama pada sifat-sifat produksi dan reproduksi yang dihasilkan, akan tetapi belum banyak telaah yang membahas tentang pengaruhHVyang dihasilkan. Persilangan antara kambing Boer dan Jawarandu, menghasilkan kambing Boerja, saat initelah banyak dilakukan di Indonesia namun nilai $\mathrm{HV}$ yang dihasilkan belum dievaluasi. Untuk itu, penelitian ini bertujuan untuk melakukan kajian potensi HV pada kambing hasil persilangan tersebutberdasar tampilan produksi berupa 
bobot badan (BB). Hal itu dapat diketahui dengan cara menghitung nilai $\mathrm{HV}$ hasil silangan secara relatif terhadap rata-rata kedua tetuanya (parents average) maupun hanya terhadap tetua betinanya.

\section{MATERI DAN METODE}

Waktu dan Tempat Penelitian

Penelitian ini dilakukan di CV Kambing Burja Malang pada periode bulan Juli-Oktober 2017 untuk proses pengumpulan data primer. Analisis data selanjutnya dilakukan di Laboratorium Produksi, Jurusan Peternakan, Fakultas Pertanian, Universitas Sebelas Maret Surakarta.

\section{Materi Penelitian}

Materi yang digunakan dalam penelitian ini adalah data BB dari kambing Boer jantan, induk kambing Jawarandu, dan hasil persilangannya (Boerja) F1, F2 dan F3 pada tahun 2012-2015. Identifikasi bangsa kambing dilakukan atas dasar catatan asal ternak, perkawinan dan pembelian di CV. Kambing Burja.

Metode persilangan untuk menghasilkan kambing Boerja dalam penelitian ini adalah sistem backcross dimana setiap anak keturunan betina disilangkan kembali dengan pejantan dari bangsa Boer dengan tetap menerapkan metode perkawinan yang meminimalisir inbreeding. Detail skema persilangan dapat dilihat pada Gambar 1. Persilangan pertama yaitu kambing betina Jawarandu disilangkan dengan pejantan Boer menghasilkan Boerja F1. Selanjutnya Boerja F1 betina disilangkan dengan Boer jantan menghasilkan Boerja F2, Boerja F2 betina disilangkan dengan Boer jantan menghasilkan Boerja F3. Diketahui bahwa pada F1, F2 dan F3 masing-masing memiliki 50\%, 75\%, dan 87,5\% komposisi bangsa Boer.
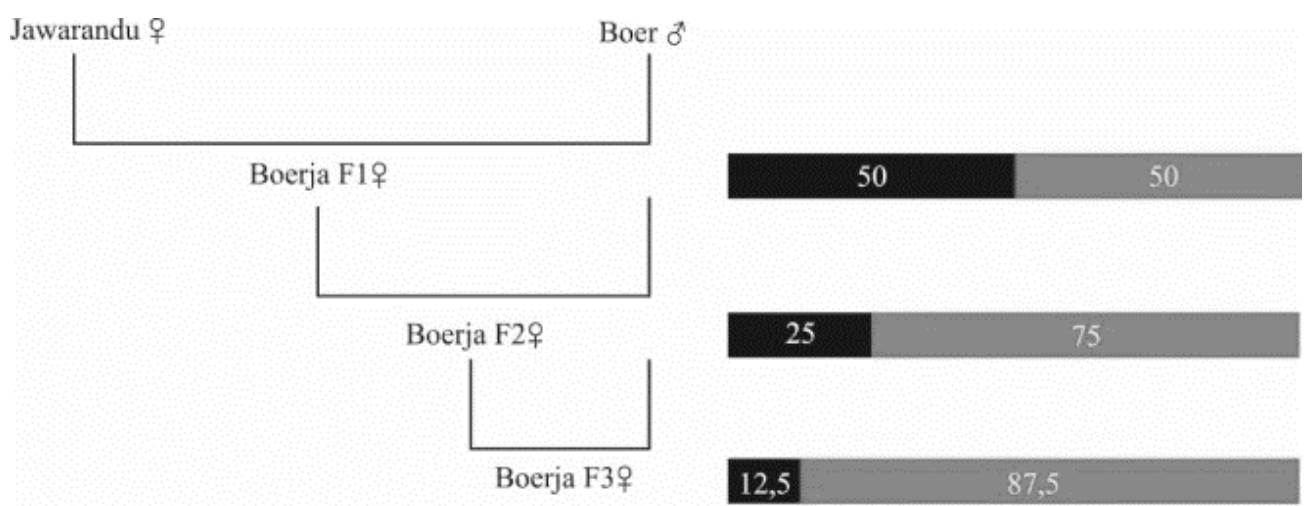

Gambar 1. Skema Persilangan dan Komposisi bangsa

\section{Metode Penelitian}

\section{Data Bobot Badan Kambing}

Variabel BB diambil dari kambing berumur 1,5tahun dan berasal dari individu ternak yang memiliki informasi lengkap berupa identitas ternak, tetua, jenis kelamin, tanggal kelahiran dan catatan
penimbangan.Penentuan umur didasarkan pada catatan kelahiran yang dimiliki masing-masing ternak melalui nomer ear taq dan dicocokkan dengan data recording yang ada. Pengukuran BB dilakukan dengan cara penimbangan menggunakan 
timbangan gantung digital kapasitas $75 \mathrm{~kg}$, dengan ketelitian $\pm 0,02 \mathrm{~kg}$.

\section{Analisis Data}

Penelitian ini merupakan penelitian observasional dalam bidang pemuliaan ternak. Data yang dikumpulkan dalam penelitian ini meliputi data jumlah kambing ( $n)$, rata-rata $(\mu)$ dan standar deviasi (sd) BB pada setiap bangsa kambing beserta silsilah tiap individu. Data tersebut selanjutnya digunakan untuk melakukan estimasi nilai $\mathrm{HV}$ relatif terhadap kedua tetua dan tetua induk betinanya (Bourdon, 2014).

\section{Estimasi HVrelatif terhadap kedua tetuanya (parents average)}

Tujuan dari perhitungan $\mathrm{HV}$ relatif terhadap kedua tetua adalah membandingkan performa anak betina hasil persilangan (crossbreed) dengan ratarata kedua tetuanya (jantan dan betina). Adapun rumus yang digunakan adalah sebagai berikut:

$$
\begin{aligned}
& \overline{\bar{P}}_{\mathrm{P}}=\frac{\mathrm{P}_{\mathrm{p} 1}+\mathrm{P}_{\mathrm{p} 2}}{2} \ldots \ldots \ldots \ldots . . . . . . . \\
& \mathrm{HV}=\frac{\mathrm{P}_{\mathrm{F} 1}+\mathrm{P}_{\mathrm{p}}}{\mathrm{P}_{\mathrm{p}}} \times 100 \%
\end{aligned}
$$

Keterangan:

$\overline{\overline{\mathrm{P}}}_{\mathrm{P}}$ : rata-rata performa dari tetua

$\overline{\mathrm{P}}_{\mathrm{P1}}$ : rata-rata performa dari pejantan

$\overline{\mathrm{P}}_{\mathrm{P} 2}$ : rata-rata performa dari induk betina

$\overline{\mathrm{P}}_{\mathrm{F} 1}$ : rata-rata performa dari keturunan

HV : Hybrid Vigor

\section{Estimasi HV relatif terhadap tetua betina}

Estimasi HV ini bertujuan untuk membandingkan performa anak betina hasil persilangan (crossbreed) dengan induknya.Adapun rumus yang digunakan adalah sebagai berikut:

$$
\mathrm{HV}=\frac{\mathbb{P}_{F 1}-\mathbb{P}_{p q}}{\mathbb{P}_{p q}} \times 100 \%
$$

Keterangan:

HV : Hybrid Vigor

$\mathrm{P}_{\mathrm{F} 1}$ : rata-rata performa dari keturunan

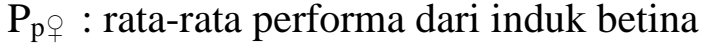

\section{HASIL DAN PEMBAHASAN Tampilan BB kambing}

Sebanyak 504 ekor kambing dari bangsa Boer, Jawarandu, Boerja F1, F2, dan F3 terpilih sesuai dengan kriteria. Rata-rata BB dari bangsa kambing yang digunakan dalam penelitian ini disajikan pada Tabel 1.

Tabel 1. Data BB kambing hasil penimbangan

\begin{tabular}{lccc}
\hline \multicolumn{1}{c}{ Bangsa kambing } & Jenis kelamin & Jumlah data (n/ekor) & BB $(\mu \pm \mathrm{sd} ; \mathrm{kg})$ \\
\hline Boer & Jantan $\left({ }^{\Uparrow}\right)$ & 6 & $79,00 \pm 16,21$ \\
Jawarandu & Betina $(+)$ & 15 & $29,07 \pm 3,76$ \\
F1 Boerja & Betina (+) & 298 & $41,84 \pm 4,12$ \\
F2 Boerja & Betina(+) & 167 & $41,69 \pm 3,68$ \\
F3 Boerja & Betina(+) & 18 & $39,96 \pm 4,97$ \\
\hline
\end{tabular}

Hasil penimbangan $\mathrm{BB}$ pejantan kambing Boer diperoleh rata-rata 79,00 kg. Sebagaimana informasi yang diperoleh dari catatan identitas ternak, pejantan-pejantan tersebut adalah kambing Boer murni yang didatangkan langsung dari Australia yang selanjutnya dipelihara dan digunakan untuk pemacek di perusahaan tempat penelitian berlangsung. Dilaporkan sebelumnya bahwa kambing Boer memiliki sifat yang unggul sebagai kambing pedaging karena memiliki kecepatan pertumbuhan dan bobot badan yang tinggi. Berat lahir kambing Boer dilaporkan berkisar 3-4 kg, dengan berat sapih berkisar $20-25 \mathrm{~kg}$. Pada umur 1 tahun, pejantan Boer dapat 
mencapai berat 50-70kg (Lu, 2001). Dilaporkan juga bahwa kambing Boer dapat tumbuh dengan rataan pertambahan bobot badan harian sebesar $0,14-0,18 \mathrm{~kg}$ per hari (Casey and Van Niekerk, 1988; Solaiman, 2010).

Rerata berat badan kambing Jawarandu yang diperoleh dalam penelitian ini adalah 29,07 kg. Hasil penelitian sebelumnya melaporkan bahwa rata-rata bobot badan kambing Jawarandu pada umur 18-30 bulan adalah 30,77 $\pm 3,48 \mathrm{~kg}$ (Mardhianna, Sukarno, dan Dilaga, 2015). Seperti diketahui bahwa kambing Jawarandu merupakan ternak lokal Indonesia, hasil persilangan antara kambing Kacang dengan kambing PE. Secara tampilan, kambing ini lebih mirip dengan ciri-ciri kambing Kacang. Disisi lain, kambing PE merupakan hasil persilangan antara kambing Etawa dengan kambing Kacang yang tampilannya mirip kambing Etawa namun ukuran lebih kecil (Batubara, Doloksaribu, dan Tiesnamurti, 2011). Berdasarkan informasi sebelumnya, apabila distratifikasi maka BB kambing Boer lebih tinggi dibanding kambing PE, dan kambing PE lebih berat dibanding kambing Kacang pada umur yang sama. Secara umum, perbedaan BB antar bangsa kambing disebutkan karena pengaruh genetik, nutrisi, kesehatan dan penyakit, usia dan metode persilangan, dan sistem pemeliharaan(Lu, 2001). Pemaksimalan potensi genetik dengan memberikan kondisi lingkungan yang optimal akan memberikan tampilan atau fenotipe yang optimal pula (Oldenbroek and Waaij, 2015).

Tampilan BB kambing Boerja F1, F2 dan F3 dalam penelitian ini berturut-turut 41,84; 41,69; dan 39,96 kg. Hasil ini menunjukan adanya pernurunan rata-rata BB kambing Boerja F1 ke F3. Disisi lain, komposisi bangsa kambing Boer meningkat dan komposisi bangsa kambing Jawarandu menurun dari F1 ke F3 (Skema persilangan pada Gambar 1). Hal ini sesuai dengan tujuan dari persilangan sistem backcross yaitu untuk meningkatkan proporsi genetik ternak impor dan menurunkan proporsi genetik ternak lokal (Hardjosubroto, 1994). Secara karakteristik fisik, peningkatan proporsi bangsa Boer menyebabkan kambing Boerja akan lebih mirip ke Boer (Gambar 2), dapat dilihat bahwa tampilan fisik kambing Boerja F3 yang paling mendekati tampilan kambing Boer. Rata-rata BB kambing Boerja F1, F2 dan F3 berada diatas rata-rata BB kambing Jawarandu dan dibawah rata-rata kambing Boer. Fenomena yang demikian, diduga sebagai akibat dari adanya pengaruh $\mathrm{HV}$.

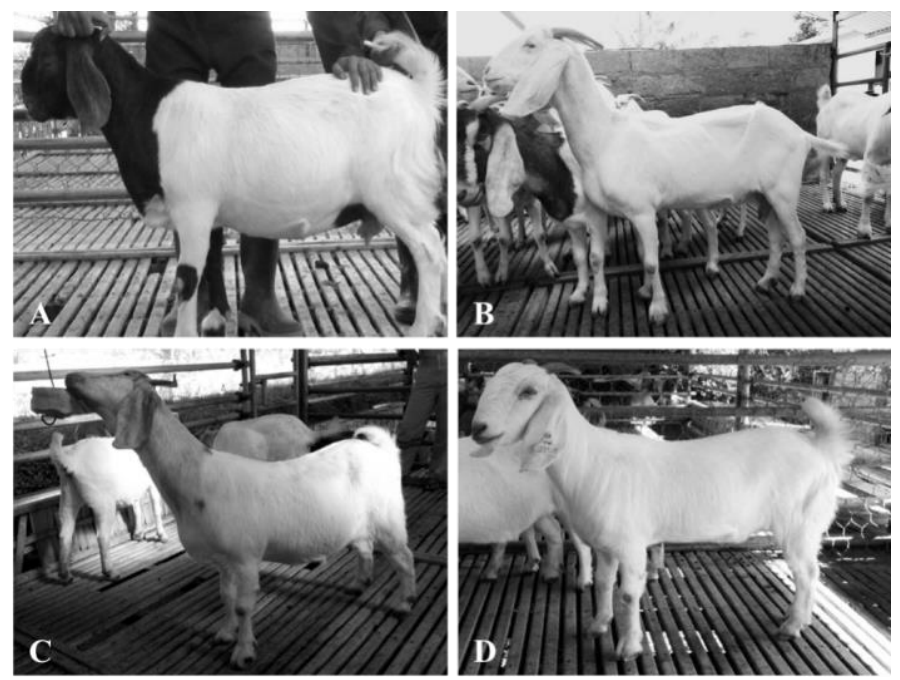

Gambar 2. Perbandingan karakteristik fisik antara kambing Boer (A), Boerja F1 (B), Boerja F2 (C) dan Boerja F3 (D). 


\section{Perhitungan $\mathrm{HV}$ pada sifat $\mathrm{BB}$}

Perhitungan nilai HV kambing Boerja F1, F2, dan F3 relatif terhadap rerata kedua tetuanya dan tetua betina disajikan pada Tabel 2. Terlihat bahwa kedua nilai HV (relatif terhadap kedua tetua dan tetua betina) mengalami penurunan seiring dengan bertambahnya komposisi bangsa kambing Boer pada F1 sampai dengan F3. Penurunan nilai $\mathrm{HV}$ tersebut juga diiringi dengan penurunan BB seperti terlihat pada Tabel 1.

Tabel 2. Nilai HV pada kambing Boerja

\begin{tabular}{|c|c|c|c|}
\hline \multirow{2}{*}{ Hasil silangan } & \multirow{2}{*}{ Tetua } & \multicolumn{2}{|c|}{ HV relatif terhadap $(\%)$} \\
\hline & & kedua tetua & tetua betina \\
\hline Boerja F1 & Boer $\left(0^{\lambda}\right) \times$ Jawarandu $(Q)$ & -23 & 44 \\
\hline Boerja F2 & Boer $\left(\delta^{\lambda}\right) \times$ Boerja F1 $(q)$ & -31 & 0 \\
\hline Boerja F3 & Boer $(\widehat{0}) \times$ Boerja F2 (ㅇ) & -34 & -4 \\
\hline
\end{tabular}

Hybrid vigor atau disebut juga heterosis merupakan fenomena dalam suatu persilangan dimana performa hasil silangannya melampaui rata-rata tampilan bangsa tetuanya (Bourdon, 2014). Ekspresi $\mathrm{HV}$ dapat diklasifikasikan sebagai pengaruh gen secara aditif dan nonaditif, relatif terhadap pola ekspresi yang diamati dari hasil silangan tetuanya. Ekspresi aditif terjadi ketika tingkat ekspresi HV sama dengan rata-rata kedua tetuanya. Ekspresi non-aditif (dominasi, overdominance dan epistasis) terjadi ketika ekspresi HV menyimpang dari rata-rata tetuanya (Springer and Stupar, 2007). Penyimpangan tersebut dapat berada diatas atau dibawah rata-rata tampilan tetuanya. Pada penelitian ini (Tabel 2) diperoleh nilai HV pada semua hasil persilangan berada di bawah rata-rata tampilan $\mathrm{BB}$ kedua tetuanya, dapat diduga nilai $\mathrm{HV}$ pada kambing Boerja merupakan efek dari ekspresi gen non-aditif. Disisi lain pada nilai HV relatif terhadap tetua betina, Boerja F1 menunjukkan nilai positif yang berarti berada diatas rata-rata kambing Jawarandu sebagai induk. Hal ini menunjukkan bahwa persilangan antara kambing Boer dan Jawarandu meningkatkan tampilan BB hasil persilangan yang lebih baik dibandingkan kambing Jawarandu, akan tetapi pola tersebut tidak berulang pada Boerja F2 dan
F3. Secara relatif tampilan Boerja F2 tidak lebih baik dibandingkan induk Boerja F1, sedangkan pada F3 ternyata tampilannya menjadi lebih rendah (negatif) apabila dibandingkan dengan induk Boerja F2.

Hasil yang sama dilaporkan pada penelitiansebelumnya pada persilangan antara pejantan kambing Boer dengan PE, memperlihatkan bahwa hasil silangan kambing Boerawa (F1) memiliki bobot lahir dan sapih yang lebih rendah dibanding Boer tetapilebih tinggi dibanding PE (Harowi, Sulastri, dan Hamdani, 2016). Sedangkan untuk F2 tidak ada informasi lebih lanjut. Dalam penelitian ini, diperoleh bahwa kedua nilai $\mathrm{HV}$ mengalami penurunan dari F1 ke F3 sejalan dengan penurunan BB. Diduga hal ini terjadi karena meningkatnya nilai homozigositas pada hasil silangan yang semakin mendekati bangsa Boer. Peningkatan nilai homozigositas tersebut semakin memperpendek jarak genetik antar individu sehingga berakibat penurunan nilai HV sekaligus tampilan BB. Nilai heterozigositas muncul maksimal karena adanya perbedaan antara kedua bangsa tetua, sehingga nilai HV menjadi maksimal hanya pada F1. Hal demikian karena kedua tetua tidak mempunyai kaitan atau berasal dari dua bangsa yang berbeda (Bourdon, 2014). 
Pengaruh nilai heterozigositas sebenarnya dapat dilihat dari frekuensi alel pada gen pengontrol tampilan BB (Javanmard et al., 2010). Mempertimbangkan bahwa nilai HV dipengaruhi oleh kerja gen-gen baik aditif maupun non-aditif, maka perhitungan frekuensi alel dominan dan resesif pengontrol $\mathrm{BB}$ dapat menjadi salah satu penjelas mengapa terjadi penurunan tampilan BB. Hal tersebut dikarenakan BB tidak hanya dipengaruhi oleh satu gen melainkan suatu sifat kompleks yang dikontrol oleh banyak gen. Implikasi dari fakta ini adalah pola pewarisan dari BB mengikuti infinitesimal model dengan asumsi bahwa fenotip yang diperoleh mengikuti distribusi normal. Pengaruh aditif dapat tercermin dari frekuensi alel sedangkan pengaruh nonaditif dapat dilihat dari nilai heterozigositas yang selanjutnya memengaruhi BB.

Bobot badan dipengaruhi oleh banyak gen (Wang et al., 2016; Zhang et al., 2013), menunjukkan variasi kombinasi alel yangmasif dan mengakibatkan perbedaan ekspresi gen yang mengontrol BB. Ekspresi gen dalam hal ini dipengaruhi oleh variasi genetik, dengan fokus pada variasi antar individu (Williams et al., 2007). Sebagai contoh, variasi genetik seperti faktor transkripsi yang mengendalikan ekspresi beberapa gen cenderung memiliki pengaruh pada semua atau sebagian besar gen targetnya. Gen tidak berdiri sendiri dalam menentukan fenotip, dimana fenotip terakhir yang nampak pada adalah hasil interaksi antara semua kegiatan gen dan lingkungan. Gen akan memunculkan ekspresi yang berupa protein yang akan memengaruhi metabolisme dan fisiologis ternak, selanjutnya terjadi perbedaan fenotip. Gen memengaruhi metabolisme karena gen mengontrol enzim sebagai katalisator dalam proses metabolisme (Suryo, 2004).

Nilai HV salah satunya dipengaruhi oleh jarak genetik antar bangsa ternak (Tambasco-Talhari et al., 2005). Jarak genetik didefinisikan sebagai derajat perbedaan genetik atau perbedaan genomic antar bangsa atau populasi mahkluk hidup (Nei, 1972), hal ini dapat dilihat dari hasil crossbreeding antara kambing Boer dan Jawarandu mencapai nilai $\mathrm{HV}$ tertinggi ketika dikawinkan sampai dengan F1 dalam penelitian ini. Nilai HV akan optimal ketika kedua tetua tidak mempunyai kekerabatan atau berasal dari dua bangsa yang berbeda (Bourdon, 2014). Hasil penelitian dari persilangan antara kambing Jawarandu dengan Boer menghasilkan BB yang cukup tinggi karena mengadopsi sifat induk jantannya yaitu sebagai salah satu penghasil daging terbaik, disisi lain kemampuan untuk beradaptasi di lingkungan tropis seperti di Indonesia karena mengadopsi sifat dari induk betinanya. Hal ini sesuai dengan salah satu tujuan dari persilangan ternak di Indonesia yaitu untuk meningkatkan performa ternak lokal, dengan cara menyatukan sifat-sifat unggul yang terdapat pada kedua bangsa kedalam satu bangsa silangan (Hardjosubroto, 1994). Berdasarkan hasil estimasi dalam penelitian ini, nilai $\mathrm{HV}$ yang relevan digunakan adalah relatif terhadap salah satu populasi dari tetua yaitu peningkatan tampilan BB terhadap induk betinanya.

Program crossbreeding tidak selalu akan memberikan efek positif kepada keturunannya, sehingga perlu perencanaan yang matang sebelum melakukannya. Crossbreeding yang dilakukan secara terus menerus tanpa evaluasi akan menimbulkan efek penurunan tampilan ternak pada sifatsifat yang harusnya menguntungkan secara ekonomis. Atas dasar hasil penelitian ini, maka, di bawah faktor lingkungan dan manajemen yang sama, persilangan yang direkomendasikan untuk memperoleh pengaruh $\mathrm{HV}$ yang maksimal adalah sampai pada Boerja F1. Meskipun demikian, tidak menutup kemungkinan proses persilangannya dapat dilanjutkan karena dimungkinkan memodifikasi faktor 
lingkungan sehingga dapat meningkatkan tampilan sebagai interaksi antara faktor genetik dengan lingkungan (Hardjosubroto, 1994).

\section{KESIMPULAN}

Keuntungan dari efek HV pada persilangan kambing Boer dan Jawarandu pada penelitian ini hanya optimal sampai pada F1. Menurunnya nilai HV terbukti menurunkan tampilan produktivitas BB kambing Boerja. Selanjutnya konservasi ternak lokal yang bukan silangan khususnya Jawarandu perlu dilakukan untuk produksi kambing F1 sebagai final stok.

\section{UCAPAN TERIMAKASIH}

Penelitian ini merupakan bagian dari Penelitian Dasar Unggulan Perguruan Tinggi yang didanai oleh Kementerian Riset, Teknologi, dan Pendidikan Tinggi melalui skema Penelitian Dasar Unggulan Perguruan Tinggi Tahun Anggaran 2018. Adapun judul lengkap penelitiannya adalah: "Pemaksimalan Respon Genetik Sifat Berat Lahir Kambing Boer-Jawa Randu (Boerja) Melalui Modifikasi Desain Breeding Pada Populasi Terbatas". Peneliti juga menyampaikan ucapan terimakasih kepada CV. Burja Malang, Jawa Timur, atas bantuan selama proses penelitian.

\section{DAFTAR PUSTAKA}

Batubara, A., Doloksaribu, M., \& Tiesnamurti, B. 2011. Potensi Keragaman Sumberdaya Genetik Kambing Lokal Indonesia. In Lokakarya Nasional Pengelolaan dan Perlinsungan Sumber Daya Genetik di Indonesia (pp. 206-214).

Bourdon, R. M. 2014. Understanding Animal Breeding (2nd ed.). United State of Amerika: Pearson New International Edition.
Budisatria, I. G. S. 2014. Carcass Characteristics of Bligon and Kejobong Goats. In Proceedings of the 16th AAAP Animal Science Congress Vol. II 10-14 November 2014 (Vol. II, pp. 973-975). Yogyakarta: Gadjah Mada University.

Casey, N. H., \& Van Niekerk, W. A. 1988. The boer goat. I. Origin, adaptability, performance testing, reproduction and milk production. Small Ruminant Research, 1(3), 291-302. https://doi.org/10.1016/09214488(88)90056-9

Cassady, J. P., Young, L. D., \& Leymaster, K. A. 2002. Heterosis and recombination effects on pig reproductive traits. Journal Animal Science, 80(9), 2303-2315.

Crow, J. F. 2001. Heterosis. Encyclopedia of Genetics, 933. https://doi.org/10.1006/rwgn.2001.06 11

Hardjosubroto, W. 1994. Aplikasi Pemuliabiakan Ternak di Lapangan. Jakarta: PT. Gramedia Widiasarana Indonesia.

Harowi, M., Sulastri, \& Hamdani, M. D. I. 2016. Perbandingan koefisien heterosis antara kambing boerawa dan saburai jantan pada bobot sapih di kecamatan sumberejo kabupaten tanggamus. Jurnal Ilmiah Peternakan Terpadu, 4(1), 67-72.

Javanmard, A., Panandam, J. M., Sugnaseelan, S., \& Yusoff, K. 2010. Allele frequencies at six candidate genes associated with growth and carcass quality traits in the Boer goats. Journal of Biotechnology, 9(43), 7236-7238. 
Kinghorn, B., Werf, J. van der, Ryan, M., van der Werf, J., \& Ryan, M. 1999. Animal Breeding Use of New Technologies. Sidney: The Post Graduate Foundation in Veterinarian Science of the University of Sydney.

Lu, C. D. 2001. Boer Goat Production: Progress and Perspective. In Proceedings of International Conference on Boer Goats. October 20-24, 2001. (pp. 1-11). Anshun, China.

Malan, S. W. 2000. The improved Boer goat. Small Ruminant Research, 36(2), 165-170. https://doi.org/10.1016/S09214488(99)00160-1

Mardhianna, I., Sukarno, S. D., \& Dilaga, I. W. S. 2015. Hubungan antara ukuran-ukuran tubuh dengan bobot badan kambing jawarandu jantan berbagai kelompok umur di kabupaten Blora. Animal Agriculture Journal, 4(2), 264-267.

Nei, M. 1972. Genetic Distance between Populations. The American Naturalist. https://doi.org/10.1086/282771

Nugroho, T., Nurhidayati, A., Ayuningtyas, A. I. I., Kustiyani, C., Prastowo, S., \& Widyas, N. 2018. Birth and weaning weight of kids from different Boer goat crosses. In IOP Conference Series: Earth and Environmental Science (Vol. 142, p. 012010).

https://doi.org/10.1088/17551315/142/1/012010

Oldenbroek, K., \& Waaij, L. van der. 2015. Textbook animal breeding. Animal breeding and genetic for BSc student. Wageningen: Center for Genetic Resources and Animal Breeding and
Genomics Group, Wageningen University and Reasearch Center, The Netherlands. Groen Kennisnet.

Shrestha, J. N. B., \& Fahmy, M. H. 2007. Breeding goats for meat production: 2. Crossbreeding and formation of composite population. Small Ruminant Research, 67(2-3), 93-112. https://doi.org/10.1016/J.SMALLRU MRES.2005.10.018

Solaiman, S. G. 2010. Goat Science and Production. Goat science and production. Iowa, USA: Blackwell Publishing.

Springer, N. M., \& Stupar, R. M. 2007. Allelic variation and heterosis in maize: How do two halves make more than a whole? Genome Research, (612), 264-275. https://doi.org/10.1101/gr.5347007.26 4

Suryo. 2004. Genetika (cetakan 10). Yogyakarta: Gadjah Mada University Press.

Tambasco-Talhari, D., de Alencar, M. M., de Paz, C. C. P., da Cruz, G. M., de Andrade Rodrigues, A., Packer, I. U., ... de Almeida Regitano, L. C. 2005. Molecular marker heterozygosities and genetic distances as correlates of production traits in F1bovine crosses. Genetics and Molecular Biology. https://doi.org/10.1590/S141547572005000200007

Wang, X., Liu, J., Zhou, G., Guo, J., Yan, H., Niu, Y., ... Chen, Y. 2016. Whole-genome sequencing of eight goat populations for the detection of selection signatures underlying production and adaptive traits. Scientific Reports. https://doi.org/10.1038/srep38932 
Williams, R. B. H., Chan, E. K. F., Cowley, M. J., \& Little, P. F. R. 2007. The influence of genetic variation on gene expression, 17, 1707-1716. https://doi.org/10.1101/gr.6981507.sp ecific

Wodzicka-Tomaszewska, M., Djajanegara, A., Gardiner, S., Wiradarya, T. R., \& Mastika, I. M. 1993. Small Ruminant
Production in the Humid Tropics. Surakarta: Sebelas Maret University Press.

Zhang, L., Liu, J., Zhao, F., Ren, H., Xu, L., Lu, J., ... Du, L. 2013. GenomeWide Association Studies for Growth and Meat Production Traits in Sheep. $P L o S$

ONE. https://doi.org/10.1371/journal.pone.0 066569 